UDC 811.111:81'372

DOI https://doi.org/10.32838/2710-4656/2021.2-1/26

Moiseienko S. M.

National Technical University of Ukraine "Igor Sykorsky Kyiv Polytechnic Institute"

Kondrashova A. V.

National Technical University of Ukraine "Igor Sykorsky Kyiv Polytechnic Institute"

\title{
PERFECT SPEECH IN THE ENGLISH COMPUTER DISCOURSE
}

The article describes the elements of the various sign systems that implement the semantics of the English computer discourse, and provide the internal integrity of the message and the imagecognitive content. The object of our research is the English computer discourse. The purpose of this study is to consider the structural and semantic features of the English computer discourse, which involves the following tasks: to clarify the meaning of "discourse" from the standpoint of the semantic approach; consider the elements of the language system that implements the semantics of the English computer discourse; to analyze the structural and compositional techniques of English computer communication. Verbal communication includes a chain of statements containing information, which is based on the interaction of material and spiritual objects and phenomena, events and situations. The role of verbal communication is to establish connections between phenomena (cognitive act), to transfer to the receiver his knowledge of the subject with the motivation that will serve as an impulse for the receiver to perform certain intellectual or material actions. Since the generator of content is the composition and syntactic design of language units, we consider the syntagmatics of discourse at all levels and identify the principles that guide the construction of discursive structures and their content. Particular attention is paid to language units with nuclear semantics as important operators in the formation of discourse. The paper also analyzes the compositional structure and determines the semantic characteristics of the compositional elements of the computer text. We analyze the structural and compositional features of the English computer communication from the perspective of the semantic approach (based on 150 texts of the English computer discourse).

Key words: communication, communicative act, semantics, sentence, sign system, sign.

Formulation of the problem. The concept of discourse arose with the advent of linguistic research beyond sentences - in the field of supra-phrase syntax. Therefore, from the point of view of linguistics, discourse is, first of all, a complex unit, which consists of a sequence of sentences that are semantically connected. Any native speaker subconsciously has a certain key principle that allows him to trace the semantic interactions of units at all levels of discourse. This deep principle permeates all levels of the language system (from phonetic to supra-phrase), which provides:

- automatic deployment of discursive structures with traditional semantics;

- control over the composition of structures in the generation of non-traditional meanings.

Since the generator of meaning is the composition and syntactic design of linguistic units, it is necessary to consider the syntagmatics of discourse at all levels and identify those principles that govern the construction of discursive structures and their semantic content. Special attention is paid to linguistic units with nuclear semantics as important operators in the formation of discourse.
The problem of semantics is at the center of attention of modern linguistics, not only because thanks to this aspect the communicative essence of language is revealed, but also because the content side of the language is directly related to the cognitive activity of a person and is an area of study of many related sciences: philosophy, epistemology, literary criticism, informatics and others which study the role of semantics in the process of knowledge formation and transmission.

The semantic approach to discourse provides the traditional description of discourse in semiotics as a purely pragmatic one, which equates the meaning of an utterance with its situational use, and a purely semantic one, which considers discourse as a global semantic structure and makes it possible to synthesize, integrate a description of discourse based on the form that is the carrier its meaning, since the syntactic form of discourse has a meaning-generating ability.

At the same time, such an approach encounters a number of limitations, since the nature of discourse is twofold, since it is, on the one hand, a product of communicative activity, and on the other hand, 
discourse is addressed to the communicative act, to speech activity. The concept of discourse is close to the concept of "linearly constructed speech", and the communicative function comes to the fore in its content. In this sense, discourse is considered from the standpoint of communicative linguistics and is defined as the central unit of speech activity, which is characterized by such basic characteristics as conditioning by extralinguistic factors, the event aspect, purposeful social action, and the definition of discourse as a text within real communication.

The object of the paper is one of the most widespread types of discourse - computer discourse. The concept of "computer discourse" can be interpreted in two ways: on the one hand, it is any communication in computer networks, communication using a special kind of signals - electronic communication signals; on the other hand, computer discourse can be defined as communication on topics related to computers. Both purposes of computer discourse are relevant to us.

The purpose of the research is to consider the structural and semantic features of the English computer discourse. Achieving this goal involves the following tasks:

- to clarify the content of the concept of "discourse" from the perspective of the semantic approach;

- to consider the elements of the language system that implements the semantics of the English computer discourse;

- to analyze the structural and compositional techniques for the design of English computer communication.

The communicative act always presupposes both complete mastery of the receiver's language and the presence of the necessary background knowledge, on the basis of which the understanding of this or that information is provided. In the process of creating a discourse, the level of knowledge of those to whom this discourse is addressed is necessarily taken into account. It is the volume of knowledge and specialization of the receiver that often determine the nature of the presentation and the structure of the discourse. In the process of communication in discourse, informational connections of communicants are realized, who have a certain level of necessary knowledge for understanding and assimilating the relevant material, while the language component of the addressee and the receiver should be equivalent, and the cognitive side of communication (full or partial perception - understanding of the content of communication) is considered within the framework of the equivalence of the thesaurus of communicants.
The thesaurus of communicants is part of the cultural and scientific competence of communicants with equal linguistic competence.

Linguistic competence determines, on the one hand, the formation of information for the receiver by the communicant, and on the other hand, the perception of this information by the receiver. Therefore, the linguistic units that structure this information have a content plan, since it is on this feature that communication itself is built, and the meaningful nature of linguistic units should be determined not from structural parameters, but from the characteristics of a real segment of reality that underlies the semantics of the corresponding linguistic unit.

In most cases, the semantic properties of linguistic signs, which are presented in a sufficiently long and dynamically developed context (discourse), differ significantly from the semantic properties of the same signs that are considered in isolation or in a short context. First of all, we are talking, of course, about the main sign - the sentence [6, p. 330].

Analysis of the recent research and publications. In modern linguistics the idea of the need to study a sentence, taking into account the typified text conditions of their use, in other words, with the obligatory output to the text, has been repeatedly emphasized. Such a study helps not only to identify new semantic and syntactic features of individual varieties of simple and complex sentences, but also makes it possible to consider them from the standpoint of functional grammar, which examines grammatical units in "relationship with elements of different language levels involved in the expression of a semantic statement" [3, p. 99].

In addition, the analysis of a sentence in its textual connections is the basis for a serious development of the theory of a coherent text, which must necessarily take into account the "compatibility of the syntactic form and semantic meaning of the same sentences that make up the structure of the text" [4, p. 34].

As you know, the sentence is the main mechanism of text formation. It is with the help of the sentence that new information is transmitted in the text during its deployment. Any sentence in the text has the ability to link with other sentences. In the implementation of this connection, lexical, lexical-grammatical and grammatical means are involved. The ordering of temporal, modal and spatial meanings in sentences and the nature of the theme-rhematic articulation perform connecting functions in the text.

The peculiarity of the English computer discourse should be recognized the existence in 
it of various sign systems expressed not only by verbal elements, but also by mathematical symbols, graphic material and tables. In the process of creating a discourse, the addressee "encodes" the message, sequentially using the formalized, verbal and graphic (diagrammatic) systems. Elements of various sign systems, realizing the semantics of the same concepts in essence, enter into various kinds of relationships, paradigmatic, syntagmatic, integrative, which ensures the internal integrity of the message and its figurativecognitive content.

A fundamental aspect of the organization of computer discourse is its "fitting" to the receiver, because it significantly affects the structure of the discourse. Toexplain this, weturn to the following analogy. The process of obtaining new information by the receiver is to articulate and comprehend this information. Because the receiver determines what to read, he searches the computer discourse for the most informative passages and, after analyzing them, decides whether the discourse information is relevant to him. Therefore, it is necessary that within the computer discourse "the principles of division and selection of the most communicatively significant segments of expression (i.e., the pragmatic separation) have to be clearly implemented" [5, p. 18].

Each receiver, participating in the act of communication, has a specific plan for finding meaningful dominants in computer discourse. Of course, each search plan is individual, because it is determined by the level of special training and the general intellectual level of the receiver. However, the clear composition of the computer discourse makes it possible to single out some of the main points in the above plan.

Presentation of the basic material. The clear composition of the English computer discourse made it possible to analyze its structure and determine the semantic characteristics of the compositional elements of the English computer text (based on 150 texts of the English computer discourse).

Information in the English computer discourse is, in fact, grouped into arrays of a general computer nature or into arrays of narrowly specialized interest. Because of this, in computer discourse it is always possible to distinguish internal (esoteric, understandable only to specialists) and external (exoteric, popular, available to non-specialists) fragments [2, p. 29]. The traditional composition of the text implies the presence of an introduction, main part and conclusion.

The introduction of the computer discourse has a heterogeneous structure and from a pragmatic point of view can be divided into the following parts: 1) general information; 2) assessment and problem; 3) information-selective, summarizing. The information integration of each part of the introduction cumulates the "sum of contents", which will be called "content cumulant" [2, p. 29]. In computer texts, content cumulants are present in each part of the introduction.

The peculiarity of the general information part of the introduction is the variety of diachronic elements, references, usual terms. The amount of content that accumulates in this part of the introduction, lays a certain information foundation of an affirmative nature. The general information part of the text may contain the following fragment of the introduction: One of the principal motivations for using OOP is to handle multimedia applications in which such diverse data types as sound and video can be packaged together into executable modules.

The assessment and problem part of the introduction is more individual. It is dominated by interrogative intonations, partial judgments of the addressee. The evaluation and problem part accumulates facts of theoretical and experimental nature. They form a conceptual barrier that separates accurate knowledge and ignorance, evidence and intuitive. Such constructions as no evidence, however, several attempts, although, in other words etc., which have a tinge of opposition, doubt, present this area of the information field: Another is writing program code that's more intuitive and reusable; in other words, code that shortens program-development time.

Logical ending of introduction will enter into the information-selective or summarizing part. Here the addressee, using neutral vocabulary, informs occasionally about the nature of the performed work, its best results. In the psychological plan it is a very important part, analyzing it, the receiver first evaluates the work as a whole. At the same time, the receiver analyzes the data and sees the marriage due the lack of information, the lack of clarity, references and has stimuli before the further understanding of the information. This part plays a role of a psychological "trap": Perhaps the key feature of OOP is encapsulation - bundling data and program instructions into modules called "objects". Here's an example of how objects work.

Thus, introduction of computer discourse is a selfcontained design and an external block of descriptive character, to which the symbolic structure is apparently uniform and verbal. The introduction of symbolic meanings has been zoomed into the first place with the tasks of the textual economy and the recognition of the receiver from the symbols of the known system 
and meaning. The number of signs in non-verbal nature to the number of verbal signs at the introduction is insignificant.

The opposite picture is observed in the main body of computer discourse. As a rule, it contains several parts, which convey theoretical and possible experimental material, discuss the obtained results, make comparisons with known facts and principles. Compared to the general information part of the introduction, the main part of computer discourse has an evidentiary character and can be considered as an algorithm of this proof.

Formalized sign systems are more convenient for the organization of the logical structure of the algorithm, which explains their important role in the main part of computer discourse. Argumentation, proof is mainly given within the coexistence of different sign systems. The interaction of these systems is determined by the pragmatics of discourse and is one of the important components of the act of communication. As an example, here is a fragment of computer discourse that contains formalized sign systems:

$\mathrm{C}++$ is an object-oriented superset of $C$ which combines the best features of a structured high-level language and an assembly language - that is, it's relatively easy to code and uses computer resources efficiently. $C$ was originally designed to write systems software but is now considered a general-purpose language.

The peculiarity of the descriptive part of computer discourse is the presence in it of a large number of binary phrases such as $C++$, superset of $C$. Their presence is important from the point of view of decoding as such two-membered structures allow to transfer new semantic value in the general virtual signs. Virtually denoted superset in the linear series superset of $C$ is specified by the denoted $C$, representing the unity of general and specific.

Thus, the statement is true: "In language there are no other means of relative and absolute actualization of virtual words, except for the semantic arrangement of verbal signs in a linear series" [7, p. 82]. Description of diagram elements using binary syntagmas allows not only to form a logical element, but also to fill it with specific computer content. As an example, let's illustrate a graphic sign system within the computer discourse:

Its reverse decoding and presentation of information in the form of a lexical set makes it possible to recognize a certain type of computer data, the description of which with the help of computer lexicon would require significant decompression of the text volume. In addition, the diagrammatic description allows compact storage of information and is a convenient way to identify various types of data. Switching of sign systems actualizes various systems of evidences that characterize the multidimensionality of complex computer objects, processes, concepts. From this point of view, the optimal combination of various sign systems within the computer discourse is not only desirable, but also necessary, since only in this case the evidence of the sign composition, its autonomy and compactness remain.

Specific information usually "flows" to the end of the discourse. Final cumulants, genetically secondary to specific information, are presented in the block of final data. At the same time, they are the final factor in solving certain cognitivecommunicative tasks, and the presence of these cumulants is important from the point of view of vocabulary, syntax, stylistics and pragmatics of the computer discourse.

A special role in the compositional plan of computer discourse should be given to the conclusion, which we consider as an element of the external block. The conclusion clarifies and specifies the information contained in the information-selective part of the introduction. It is the final element of the external information unit. An additional important function of the con-

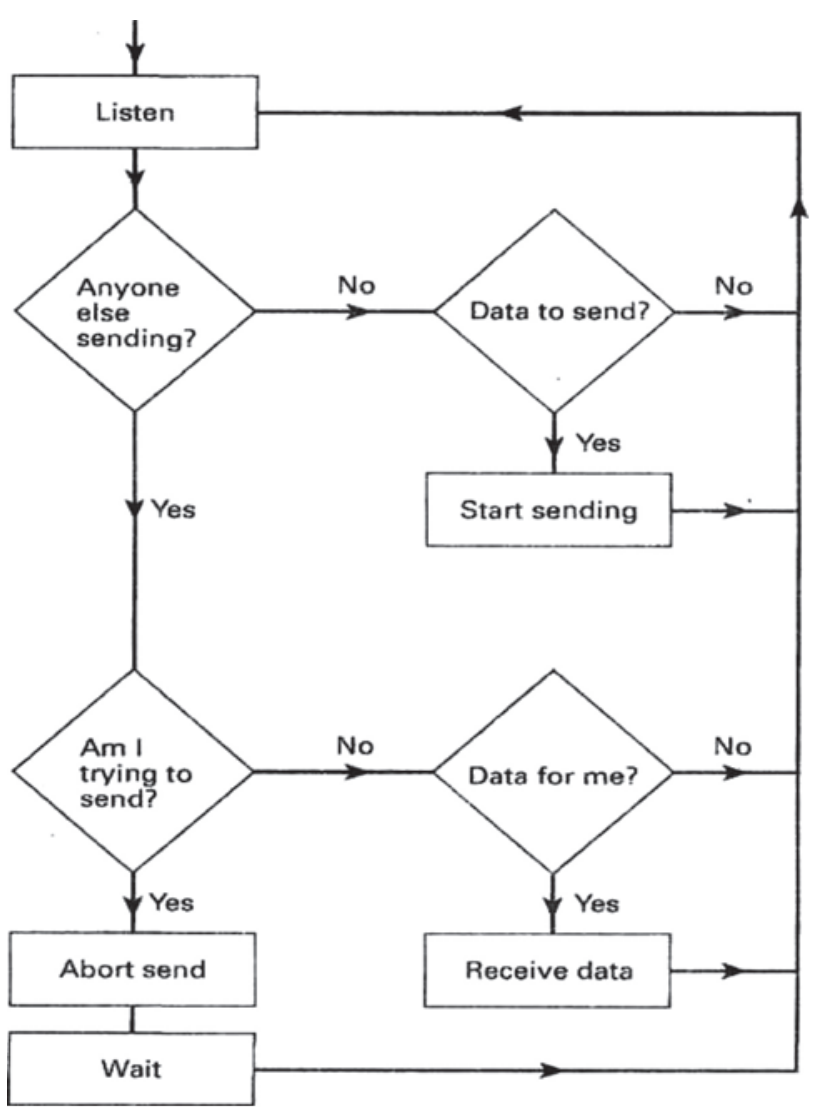

Fig. 1. The Bus/Ethernet network configuration 
clusion is to predict further research and opportunities, which is very important for the addressee. A characteristic feature of the conclusion is its complete deformalization, because "formalization is relevant where the researcher is faced with quantitative patterns of the world or patterns that involve a clear logical calculation" [1, p. 47]. In conclusion, the addressee moves to the level of qualitative interpretation, which dramatically reduces the likelihood of elements of formalized languages.

Conclusions and prospects of further investigations. The presence of signs and symbols of different nature in the English computer discourse testifies to its multifunctionality, the main components of which should be pragmatics and adequate reference correlation. The explicit expression of the information block in the English computer discourse is achieved by the active involvement of both verbal and nonverbal means, with structural and compositional factors, as well as traditional methods of design of a scientific work play not the least role here.

Thus, in the English computer discourse there are always tools that increase the level of saturation of cognitive information. The English computer discourse is characterized by a lack of emotional coloration, widespread synonymy, terminology that does not depend on the context. The absolute predominance of cognitive information in the English computer discourse determines the logical rather than the associative-figurative way of its construction, which is provided by special linguistic means, i.e. means of semantic and formal cohesion.

\section{References:}

1. Березин Ф. М., Головин Б. Н. Общее языкознание. Москва : Просвещение, 1979. 416 с.

2. Бех П. А., Тарасова Т. А. Некоторые особенности структурно-семантической организации научного текста. Научный и общественно-политический текст: лингвистические и лингводидактические аспекть изучения / отв. ред. А. М. Соколова. Москва : Наука, 1999. С. 27-39.

3. Большая советская энциклопедия : в 30 т. Т. 12. / А. И. Прохоров и др. ; 3-е изд. Москва : Сов. энцикл., 1973. 624 с.

4. Воробьева О. П. Текстовые категории и фактор адресата. Киев : Вища шк., 1993. 200 с.

5. Наер В. Л. Прагматика научных текстов: (вербальный и невербальный аспекты). Функииональные стили: Лингвометодические аспекты. Москва : Наука, 1985. 239 с.

6. Степанов Ю. С. В поисках прагматики: (Проблема субъекта). Моксва : АН СССР, 1981. Т. 40. № 4. С. 325-332.

7. Уфимцева А. А. Лексическое значение: (принцип семиологического описания лексики). Москва : Наука, 1986. 241 с.

\section{Мойсеснко С. М., Кондрашова А. В. ДОСКОНАЛЕ МОВЛЕННЯ В АНГЛОМОВНОМУ КОМП'ЮТЕРНОМУ ДИСКУРСІ}

У статті розглянуто елементи різних знакових систем, що реалізують семантику англомовного комп'ютерного дискурсу і забезпечують внутрішню иілісність повідомлення та його образнокогнітивне наповнення. Об'єкт намого дослідження - англомовний комп'ютерний дискурс. Метою даного дослідження є розгляд структурно-семантичних особливостей англомовного комп 'ютерного дискурсу, що передбачає виконання таких завдань: уточнити зміст поняття «дискурс» із позиції семантичного підходу; розглянути елементи мовної системи, щь реалізує семантику англомовного комп 'ютерного дискурсу; проаналізувати структурно-композиційні прийоми оформлення англомовної комп'ютерної комунікації. Вербальна комунікачія включає ланщюг висловлювань, щяо містить інформацію, в основі якої лежсить взаємодія матеріальних і духовних предметів та явищ, подій і ситуацій. Роль вербальної комунікації полягає у встановленні зв'язків між явищами (пізнавальний акт), у передачі адресату свого знання предмета з тією мотивачією, яка служитиме імпульсом для виконання адресатом певних інтелектуальних чи матеріальних дій. Оскільки генератором змісту є композиція і синтаксичне оформлення мовних одиниць, ми розглянули синтагматику дискурсу на всіх рівнях і виявили ті принщипи, які керують побудовою дискурсивних структур та їх змістовим наповненням. Особлива увага приділялася мовним одинииям з ядерною семантикою як важливим операторам у формуванні дискурсу. У роботі також проаналізовано композиџійну структуру і визначено семантичну характеристику композиційних елементів англомовного комп'ютерного тексту. Нами було проаналізовано структурно-композииійні особливості оформлення англомовної комп'ютерної комунікації з позииї̈ семантичного підходу (на матеріалі 150 текстів англомовного комп'ютерного дискурсу).

Ключові слова: комунікація, комунікативний акт, семантика, речення, знакова система, знак. 